\title{
THE POWERS AND LIMITS OF PLURALISM IN THEOLOGY
}

\author{
E M Conradie \\ University of Stellenbosch
}

\begin{abstract}
According to David Tracy, plurality and ambiguity are two important characteristics of the contemporary global (and South African) cultural, political, religious and theological situations. This article identifies five possible conceptual strategies to deal with the existence of a radical plurality within Christian theology, $i$ e monism, eclecticism, relativism, agnosticism and pluralism. The presuppositions of a pluralistic strategy is analysed in more detail. The appeal of such a pluralistic approach is illustrated with reference to Tracy's proposal of an analogical imagination. A few possible objections regarding the applicability of pluralism within the context of Christian theology are also discussed.
\end{abstract}

\section{The plurality within Christian theology}

In the title of his work, Plurality and ambiguity: hermeneutics, religion, hope, David Tracy accurately identifies two characteristics of the current global cultural, religious and theological situation.

Tracy uses the word 'ambiguity' as a historical and not primarily as a literary category. It indicates in the words of Walter Benjamin that

... every great work of civilization is at the same time a work of barbarism (Tracy 1987:69).

The presence of ambiguity in our so called 'post-modern' culture is unmistakable, although it is probably a euphemism considering the political, economic and technocratic oppression, the suffering, poverty, the sexism, racism, classism and elitism (and its religious legitimations) still prevalent in the late twentieth century. 'Ambiguity' is perhaps also a reasonably accurate description of South Africa in 1991. The various liberation, black and feminist theologies count as the most serious theological attempts to deal with the existence of ambiguity in the South African context.

The priority which these ambiguities duly receive on the theological agenda should, however, not distract our attention from the second aspect which Tracy raises in the title of his work $\mathrm{i}$ e the existence of plurality in culture and theology. One does not 
have to be a prophet to guess that the issues regarding plurality will become increasingly important on the political, economic, religious and theological agendas when we enter the post-apartheid phase in South Africa. Concentrating on the work of David Tracy, this article calls our attention to this phenomenon of plurality within the context of Christian theology. Various conceptual strategies to deal with plurality in theology are identified, and one of them i e pluralism is discussed in more detail.

The process of pluralisation does not only characterise the so called post-modern Western culture (cf Berger 1979:1-16). It is indeed possible to talk about an

... emerging global culture of pluralism (Tracy 1981a:355).

Christian theology is also characterised by an almost chaotic and conflicting plurality. This is described by Gordon Kaufman:

That the contemporary theological scene has become chaotic is evident to everyone who attempts to work in theology. There appears to be no consensus on what the task of theology is or how theology is to be pursued (Kaufman 1975:ix).

The existence of 'plurality' (in theology) indicates more than a harmonious or complimenting diversity. ${ }^{1}$ Different theological traditions can relate to one another in either a complimenting or a conflicting ( $i$ e besides similarities also irreducible differences), or a contradicting (implying mutually exclusive truth claims) way. The concept 'plurality', as it will be used in the present essay, indicates a diversity with conflicting truth claims. In such a plurality it is not possible to harmonise the radical differences or to identify one common denominator. There is, however, also no clarity concerning the truth status of any one approach above that of others. There is, in other words, a 'rough parity' (Gilkey 1985:725f) between the various theological truth claims.

An experience of plurality can be described aptly by the adjectives fascinans and tremendum. On the one hand the existence of plurality yields possibilities of fruitfull interaction and mutual enrichment. Tracy (1979:24) for instance, says that

The new possibilities ..., the new vision of reality provided by the ever greater range of distinct theological options can be and is enriching to the point of fascinans.

1. This article does not deal with the problem of the relation between unity and diversity in Christian theology. When the question is formulated in terms of the nature of unity amidst a harmonious diversity (or the legitimacy of diversity within an encompassing unity) the necessity of some kind of unity between the various theologies, is generally accepted. This does not, however, settle the more difficult problems of the nature of such an unity or the criteria for a legitimate diversity. This article deals with plurality (the existence of radical, conflicting differences) and pluralism (one possible reaction towards plurality). In a pluralistic approach the existence of some describable unity among Christian theologies is not taken for granted. The present article is an attempt at one possible theological evaluation of a pluralistic approach in theology. 
On the other hand it is also true that the present 'teeming buzzing confusion (James) leads to a situation where

... the formerly clear unity now seems lost to view in the ever-expanding many (Tracy 1979:24).

The integration and Geborgenheit brought about by the former unity dissapears leading inevitably to an experience of anxiety, accurately described as tremendum.

The current plurality in theology does not merely involve the coexistence of a quantitative diversity of theological schools as has indeed always been the case in Christian theology. According to Karl Rahner (1967:96-7) a qualitative pluralisation, with no possibility of an overarching synthesis, is present in theology. There is no consensus on either the agenda of theology, or the methodological principles by which theological disputes can be settled.

The existence of plurality in theology could be related to various factors. It could be argued that it arises from different confessional backgrounds. Some would like to stress, not the theoretical differences, but the different forms of Christian praxis or spirituality, upon which theology reflects. Others will stress the influence of the particular socio-political context from which theological reflection is done or the particular implicit conversation partner in each case. Yet another approach would stress the irreducible plurality within the Bible itself (e g Käsemann). It is also possible to locate the plurality as basically a plurality of ways of doing theology, a plurality of conceptions of truth or a plurality of language, cultural or symbolic worlds (cf Berger). All these possibilities actually emphasise the very fact that our theological culture can adequately be described by the term 'plurality'.

For the purposes of this essay, the role of plurality within the field of theological methodology will be emphasised. The explosion of new theologies since the sixties has led to an increasing methodological interest in theology. This was described by Tracy (1975) as a 'blessed rage for order'.

This (perhaps exaggerated emphasis? ${ }^{2}$ ) methodological interest can easily be related to the experience of plurality itself. A consciousness of plurality necessarily leads to an intensification of the question as to how and according to which criteria one is to determine the truth status of conflicting truth claims. This is in itself a methodological question. On a more existential level, the consciousness of plurality

\footnotetext{
2. There is a real danger that this methodological interest in Christian theology could lead to a 'pathological selfreflexiveness' (Kierkegaard). This is also the suggestion of Karl Rahner's well known phrase: 'We cannot spend all our time sharpening the knife; at some point we must cut!' (also quoted by Tracy 1981b:121). See also Jennings's warning (within the context of the USA): 'There is a growing danger that the work of theology is being replaced by the work of preparing to do theology. Increasingly, questions of method take on a life of their own, absorbing the energy of theologians and endlessly deferring the work for which they claim to be laying the foundations or preparing the prolegomenon' (1985:2). Gilkey (1985:96) also speaks of 'the temptation to linger so long in the preparatory enterprise of hermeneutical method, of answering the question of how to go about doing theology, that the theologian never in fact realizes, represents, or reexpresses a single aspect of the original message'.
} 
leads to the question of how the truth claims of one's own theological tradition could be maintained. This involves the further (methodological) issue of how a theology, conscious of such a conflicting plurality of theologies, could or should be done (if at all).

This interest in methodological issues in theology was, however, not only caused by the plurality within theology. The results of this methodological research, which was supposed to stabilise the pluralising process, are just another illustration of the existing radical plurality in Christian theology. Apparantly no de facto or de iure description of the nature of theology is able to gather a consensus which could provide some methodological tools to enable the theological community to discuss (and maybe settle) theological disputes.

It seems therefore that the existence of plurality in theology is an significant characteristic of the current theological scene. Peters (1983:843) is correct when he adds:

The existence of these differences cannot be wished away; they cannot be uprooted or overcome, absorbed or ignored, assimilated or dissipated. They are an indelible characteristic of modern life.

Sociologically, some reaction to this plurality is inevitable. An important (practical) question which Christian theology should therefore put to itself concerns the search for an appropriate reaction towards this plurality within theology. What conceptual strategy can be regarded as the most adequate one to deal with this plurality? What way or style of doing a theology amidst such a plurality should be considered adequate? In the next section I would like to identify five possible basic conceptual strategies towards plurality.

\section{Conceptual strategies dealing with conflicting plurality ${ }^{3}$}

a) A first possible reaction to the existence of plurality could be described as being monistic. This strategy involves an attempt to establish some kind of unity amidst an existing conflicting plurality. Such an approach can be found especially in scholastic, propositionalist (see Lindbeck 1984), fundamentalist, biblicist, evangelical 4 and orthodox theologies.

3. See the different, but related typologies for dealing with plurality by Booth (1979:425) and Marty (1980:37f). Booth identifies six strategies dealing with a conflicting plurality: 1) stimulating chaotic conflict, 2) attempting to overcome the plurality through semantic analysis, 3) monism, 4) scepticism or relativism, 5) eclecticism and 6) pluralism. Marty on the other hand identifies four basic strategies i e 1) wishing plurality away, 2) searching for a synthesis, 3) attempts to eradicate plurality and 4) living with plurality creatively.

4. See Jacobsen's (1987:325335) analysis of evangelical theology. He comments: 'Within a monistic framework this traditional evangelical vision of theology functions as follows: if the Bible contains only one system of meaning and if, as evangelical repeatedly affirm, the Bible is the normative source for all theologizing, then all evangelical theologizing logically should be theologizing ever de novo from the 
The key to the unity which is sought for in a monistic approach, can be found in different ways. 1) The truth status of one particular tradition (usually the own tradition) could be accepted and critically distanciated from any other truth claims. The own tradition thus become the criterium for orthodoxy (Rossouw 1972:206). At most, some 'moments of truth' may be acknowlegded in other traditions (although these are better accomodated within the own tradition!). 2) An attempt may be made to formulate, descriptively or normatively, a kind of highest common factor, an essential core of 'fundamental' Christian doctrine amidst the existing conflicting plurality. 3) Yet another possiblity would be to formulate a lowest common denominator, an inclusive framework within which the various truth claims could be accommodated.

In these attempts radical plurality is evaluated negatively. At most, a harmonious diversity in theology is permitted. There is usually a search for a more exact formulation of Christian truths. It may be acknowledged that a final formulation is unattainable because of the limitations of our human knowledge, but a more final expression of Christian truths remains the ideal within a monistic frame of reference.

A monistic approach to plurality is related to the typically modern search for an archimedian point on which all truth claims could be grounded, a steadfast anchor with which the endless flood of relativism could be kept at bay. This search is described by Bernstein as 'objectivism', i e:

... the basic conviction that there is or must be some permanent, ahistorical matrix or framework to which we can ultimately appeal in determining the nature of rationality, knowledge, truth, reality, goodness, rightness.

Existentially, objectivism involves a search for unity amidst a conflicting and radical plurality, a search for an unchanging, all-powerful God with whom security and rest can be found from the anxiety threatening our everyday life (Bernstein 1983:16).

Critical evaluations of a monistic approach usually reflect on the lack of openness for other traditions and the dogmatic, absolutistic and authoritarian attitude of such an approach. Tracy (1981a:451) remarks, for example, that:

Fundamentalists, traditionalists and dogmatists in every movement of thought need not trouble with a messy pluralism. They already know the truth - a truth, it seems, that sets them free from the world, but never for it.

A monistic approach is also problematic in a post-modern age where 'any pretensions to full self-presence, any congratulory western resting in an untroubled, alinguistic, self-present, reality finding ego...' is exposed as false and illusionary (Tracy 1987:59).

b) A second approach to plurality is that of eclecticism. In an eclectic approach an attempt is made to accommodate various theological traditions by identifying

\footnotetext{
Biblical text and in that activity of theologizing broader and deeper vistas of the unity of the Bible should continually be uncovered' (1987:327).
} 
legitimate truth claims, including them within one new comprehensive and overarching theological system. An eclectic approach is seen by Wayne Booth (1979:22) to be just another form of monism. The system within which the diversity is accommodated establishes in itself a certain unity. In addition, eclecticism seldomly satisfies those who are included within a sometimes foreign system. It is also far more abstract than the particular theologies it tries to include (Lash 1984:98). Tracy (1981a:40) also warns about the dangers of eclecticism:

The manner in which a call for pluralism (of methods, frameworks, etc) can easily slide into its caricature, eclecticism, if it does not develope criteria of relative adequacy for adjudicating disputes, is dismaying in contemporary theology.

c) Another possibility is that of relativism. An extreme form of relativism would argue that all theological traditions contain aspects of truth. It is not possible nor desireable to elevate one theological tradition above any other. The one is as good as the other. From a positive perspective, categories like openness, tolerance and creative play ('let a thousand flowers bloom') become the point of departure for a relativist reaction to plurality in theology.

A milder form of relativism would involve the rejection of any objective vantage point for evaluating any particular theological tradition. Every attempt at such an evaluation is, according to this approach, influenced by the historical and cultural presuppositions of the context from which other traditions are evaluated. Relativism is thus born from an insight in the way human knowledge is structured by one's own historical, cultural and linguistic context. There is no neutral, all-inclusive description of other traditions possible. There are no universal values or fixed criteria according to which the truth status of theological claims can be debated. This is also emphasized by Bernstein (1983:8) in his description of relativism:

Relativism is the basic conviction that when we turn to the examination of those concepts that philosophers have taken to be the most fundamental whether it is the concept of rationality, truth, reality, right, the good, or norms - we are forced to recognize that in the final analysis all such concepts must be understood as relative to a specific conceptual scheme, theoretical framework, paradigm, form of life, society or culture. Since the relativist believes that there is (or can be) a nonreducible plurality of such conceptual schemes, he or she challenges the claim that these concepts can have a determinate and univocal significance. For the relativist there is no substantive, overarching framework or single metalanguage by which we can rationally adjudicate or univocally evaluate competing claims of alternative paradigms.

Relativism is often criticised from a rationalist point of view. However, this critique seems to underestimate the pervasiveness of relativism in a post-modern culture. Langdon Gilkey (1985:727 is correct when indicating that 
... the current of relativism in our time runs very, very deep. Apparantly there is neither a secular nor a religious standpoint or center from which either reflective interpretation or constructive political action may proceed.

Relativism is also criticised as being yet another form of absolutism (i e with reference to the postulate that 'everything is relative' 5). Another problem with relativism is that it could lead to a situation of 'tolerance by default' (Ellul 1987:216) where everything is acceptable and nothing therefore taken seriously (Tracy 1981a:ix). A more serious issue is the apparant inability of relativism to cope with the demonic trends present in all cultures (Gilkey 1985:728). The proclamation of a status confessionis within the South African context is an indication that every kind of theology is apparantly not acceptable. From an ethical point of view, relativism could therefore be regarded as an unsatisfying approach to plurality and ambiguity.

d) The experience of a conflicting plurality of theological traditions can also lead to a degree of scepticism or agnosticism where the truth status of all truth claims are cast into doubt. Ellul (1987:216) uncovers something similar within the context of theology itself when commenting on trends in liberal theology:

There is nothing absolute, there is not a jot or title in the Bible of which we can be sure, there is nothing left of absolute truth ... As for dogmas, we consider them unworthy of interest because, at bottom, they are nothing more than opinion.

In South Africa, a sceptical view is identifiable with those doubting the possibility of Christianity's contribution to the struggle for justice and liberation, for the reason that the churches are themselves 'trapped into apartheid' (to use a phrase of VillaVicencio). Radical scepticism is open to a tu quoque argument in the sense that a sceptical attitude should also prevail over an attitude of scepticism itself. Wittgenstein's comment that: '... if you tried to doubt everything, you would not get as far as doubting everything' (quoted in Norris 1982:132) should therefore be taken seriously.

e) A fifth possible approach towards plurality is that of pluralism. The concept 'pluralism' must be distinguished carefully from the concept 'plurality'. Pluralism indicates a specific philosophical approach which could be used to deal with the empirical reality of plurality. Pluralism is thus one possible reaction or attitude towards plurality.

An exact definition of 'pluralism' is problematic and an attempt to formulate an exact definition of pluralism would be an injustice to some of the most basic tenets of pluralism. Furthermore, pluralism is not primarily an intellectual development; it is a practical attitude, a way of living, based on the desirability of tolerance and compromise (Davis 1974:237). The word is also used in a variety of contexts

5. There is an important difference between nontotalitarian absolutes and the totalitarian ones that often characterise monisms. A relativistic counter argument against the claim that relativism is also absolutistic (i e, 'everything is relative'), could be that 'it might be the case that everything (or most things) might be relative'. 
concerning the existence of plurality in that context. Therefore it is possible to identify a cultural pluralism, a political pluralism, a religious pluralism, a philosophical pluralism, a dogmatic pluralism (see Schillebeeckx 1970, Lonergan 1972) and a theological pluralism.

Pluralism is usually critically contrasted to monism. This is done by Wayne Booth (1979:339) in the following way:

A monist, even of the most generous kind, says to his opponents something like this: 'I will listen to you as best as I can, in order to discover whether there is anything in what you say that might help me improve my monism. Now, having listened, I can show you what is wrong in your position - though I may borrow some of your insights'. The pluralist, in contrast, will characteristically engage with opponents like this: 'Presumably, what you have said can lead us further. Let's begin by being sure I have understood you, and then let's see where it leads, what it enables us to do, and what, if anything, it prevents us doing'.

This comment of Booth can be explained in the following way: pluralism involves both a rejection of certain monistic ontological and epistemological views. In the case of monism it is accepted that, in the final analysis, reality portrays a unified character. According to William James

Monism ... insists that when you come down to reality as such ... everything is present to everything else in one vast instantaneous co-implicated completeness - nothing can in any sense, functional or substantial, be really absent from anything else, all things interpenetrate and telescope together in the great total conflux.

Against this accent on the unified structure of reality, the irreducible multiplicity of and the conflicting plurality within reality is emphasised in pluralistic philosophies. James (1909:322-3) formulates this classically:

Briefly it is this, that nothing real is absolutely simple, that every smallest bit of experience is a multum in parvo plurally related, that each relation is one aspect, character or function, way of its being taken, or way of its taking something else; and that a bit of reality when actively engaged in one of these relations is not by that very fact engaged in all the other relations simultaneously.

The prevailing emphasis in modern philosophy on the irreducible plurality of our (social and linguistic) reality need not, for present purposes, be analysed at length. It is sufficient to recall Tracy's analysis in chapter 3 of his work, Plurality and Ambiguity. Here he refers to the role of the rise of historical consciousness, the 'hermeneutical turn and the Heideggerian turn to the subject and also the 'linguistic turn' with the important contributions of Wittgenstein (the irreducible plurality of language games) and Derrida in this respect.

A monistic ontology usually correlates epistemologically with the ideal of certain knowledge. In the midst of historical change and contingency, an attempt is made to formulate, as far as possible, certain truths which is not subject to change. Against 
this ideal of certain knowledge, the relativity and provisional character of human knowledge is emphasised in a pluralist frame of reference:

... the pluralistic view ... is willing to believe ... that the substance of reality may never get totally collected, that some of it may remain outside of the largest combination of it ever made (James 1909:34).

A pluralist epistemology stresses the only relatively adequate nature of knowledge and therefore the necessity of a plurality of truth claims.

These ontological and epistemological presuppositions of pluralism should not be reduced to a perspectivistic view of reality. This view can be illustrated with the well known analogy of the blind men and the elephant (Booth 1979:29-34). In the analogy none of the blind men (who are all touching one part of the elephant) are able to identify the elephant as such. However, by sharing their various perspectives on the object they are investigating, they are able to come to the conclusion that they have to do with an elephant. It is important to see that the analogue presupposes one harmonious whole, namely the elephant. It is for this very reason that the diversity of perspectives on the elephant is completely in accordance with one another. Each perspective is as legitimate as all the others. In the end the analogue only stresses the limited nature of human knowledge.

Pluralism comprises of more than just an experience of limitedness or an acceptance of diversity. A pluralist attitude accepts the fact that a meta-perspective on the whole of reality might not be possible at all. The very search for such meta-perspectives is discredited. Any positive statement on the ultimate unity (or, for that matter, plurality) of reality is therefore suspect. The only reality we know of is that with which we are confronted daily. And this, pluralists argue, involves an experience of radical and conflicting plurality which cannot easily be brought under a single heading. Unity within this radical plurality is apparantly not easily found.

Admittedly, in the earlier pluralist philosophies such meta-perspectives were formulated in terms of a pluralist ontological theory. However, pluralism in this instance ends up in an interesting paradox. Such a form of pluralism is open to a $t u$ quoque-argument in the sense that a categorical rejection of monism and dualism raises the question whether pluralism does not display the same absolutistic features. Pluralism is then just a meta-perspective of a different kind. A further problem is the variety of existing pluralistic models which result in the question whether a 'pluralism of pluralisms' is needed.

In the light of these 'paradoxical umbrellas' (Booth 1979:29,92), it is perhaps more fruitful to use an epistemological rather than an ontological approach. Booth (1979:25-6 italics-EMC) says in this respect that

We are thus seeking to learn whether we need more than one way of working on the world, and we are not initially interested in conceptions of the world's ultimate nature.

In this respect Booth is also followed by Tracy. 
Pluralism in this form refrains from any search for a final (ontological) grip on the whole of reality ( $\mathrm{i}$ e neither a pluralistic grip). It uses as its starting point the empirical reality of a radical, conflicting plurality of truth claims. Pluralism presupposes an openness for the possible truth status of a plurality of conflicting (not contradicting) truth claims. One of the most significant features of pluralism is its ability or willingness to cope with a plurality of conflicting truth claims without any attempt to reconcile the differences through a more comprehensive monistic synthesis (see Ellis 1981:86). Pluralism thus displays an openness for a variety of (theological) traditions without elevating any one particular tradition above the other or using one as the criterium for others.

The category of openness does not, however, have the final word. Pluralism implies no laissez-faire attitude toward truth questions. The development of criteria 6 according to which any particular truth claim can be critically evaluated, is of the utmost importance for pluralists like Booth and Tracy. Tracy remarks in this respect:

The notion 'pluralism' need indicate neither a 'repressive tolerance' (Marcuse) nor a 'bourgeois complacency' (de Beauvoir). True pluralism develops criteria of relative adequacy (and is, thus, distinct from its caricature: an easy relaxed eclecticism). Pluralism demands conversation and expects conflict (Tracy 1981a:366).

Pluralism is thus a methodological point of departure to deal with the existing plurality (in theology). On the one hand it involves an openness for theological approaches of a radically different nature as that of the own tradition. On the other hand it also involves the identification of criteria according to which any particular theological tradition can be critically evaluated. A pluralistic attitude thus emphasises both an openness for plurality and a resistance to ambiguity (Tracy 1987), both an inclusive openness and an excluding critical judgement (Tracy 1981:514), both a 'hermeneutics of generosity' and a 'hermeneutics of suspicion' (Miles 1987:38).

\section{The appeal of pluralism: the analogical imagination}

The appeal of a pluralistic approach is probably connected to an accent on the classical liberal values of openness, tolerance and freedom, and a rejection of absolutist or dogmatist biases. For the purposes here, the appeal of pluralism can be analysed further, with reference to the conceptual proposal of an 'analogical

\footnotetext{
6. The possibility of identifying such criteria is, seen from a pluralist or relativist perspective, obviously problematic. For present purposes, it is not necessary to dwell on the detail of Booth's and Tracy's respective positions. It is only important to note that the search for criteria does become very important for a pluralist approach in theology. Suffice to say that Tracy explains the role of criteria in terms of a hermeneutical analysis of the nature of theology (see 1981a:1212) and on the nature of discourse (Ricoeur) or on the ordinary rules for conversation (1987:26).
} 
imagination' introduced by David Tracy ${ }^{7}$, one of the most well-known recent defenders of a pluralistic approach in theology.

What is an 'analogical imagination'? I would like to suggest that at least three layers of meaning can be identified.

In the first place it can be viewed as a de facto description of the nature of theology. This can be deduced from Tracy's wellknown definition (1985:36) of theology:

Theology is the attempt to establish mutually critical correlations between an interpretation of the Christian tradition and an interpretation of the contemporary situation.

The correlations established in theology can vary between relations of identity, similarity, analogy, or difference to radical nonidentity. However, it is clear from Tracy's whole ouevre (1982:237) that the correlations established between the 'Christian tradition and the 'contemporary situation' is in fact analogical:

What we usually find from the theological side when we try honestly to correlate are, I believe, analogies, not identities (Tracy).

According to Tracy, analogies are the expression of some similarity-in-difference.

Tracy therefore sees theology as being a search for analogical relations between the Christian tradition and the contemporary situation. The very possibility of identifying such correlations depends on the capacities of the human imagination. In this connection, Tracy recalls a remark by Aristotle:

The power to spot the similar in the dissimilar is the mark of a poetic genius (Tracy 1981a:410).

The imagination (cf imago) is also the way in which the analogically perceived correlations are expressed in an intersubjectively available form ${ }^{8}$. Theological interpretation is therefore, seen de facto, only possible in an analogical way and then through the role of the imagination by which certain similarities-in-differences are identified and expressed in a publicly available form.

\footnotetext{
7. Tracy is an enthusiastic supporter of a pluralistic approach. He says for example: 'Pluralism more exactly, perhaps, a pluralistic attitude ... is an attitude I fundamentally trust' (Tracy 1987:90). Tracy defends a pluralistic approach in all his most important works and in many articles on the same subject. This is evident from titles like: Blessed rage for order: the new pluralism in theology, The analogical imagination: Christian theology and the culture of pluralism, and Plurality and ambiguity: hermeneutics, religion, hope. The importance of Tracy's theological work is also evident from the many articles published on his theology and the theological discussion in the United States in general.
}

8. Readers of The analogical imagination may note the importance of the notion of expression in the interpretation event. Expression in some particular form plays a role in Tracy's analysis of the classic (composition, genre, style all of which is explicitly linked to the role of the linguistical imagination), in his analysis of the religious classics (manifestation, proclamation and emancipating praxis) and in his analysis of the Christian classic (the various genres of the New Testament). 
Secondly, the analogical imagination also functions, via an intensification of the role of the creative imagination, as a de iure understanding of how theology ought to be done. The role of the imagination is intensified in the sense that a greater openness is required to see the possibility of a novum in that which is radically different from the own tradition. A more creative search for analogical relations is also called for. Tracy therefore exhorts us to take the risk of selfexposure which is required in an authentic theological conversation:

For the phrase 'an analogical imagination' simply reminds us that conversation occurs if, and only if, we will risk ourselves by allowing the questions of the text. We must follow those questions however initially different, other, or even strange until the unique result of this kind of interaction occurs: the exploration of possibility as possible and thus similarity-in-difference. In such moments of recognition, what is both disclosed and concealed as other and different becomes appropriated as possibility. When possibility enters, some similarity-in-difference cannot be far behind (Tracy 1987:20).

In this aspect, the analogical imagination functions as a heuristic strategy for theological conversation (the metaphor Tracy uses to describe the nature of theological actions):

As a heuristic and pluralistic strategy it (the analogical imagination) ... can remind conversation partners that difference and otherness once interpreted as other and as different are thereby acknowledged as in some way possible and, in the end, analogous (Tracy 1987:93).

According to Tracy, the intensification of the role of the imagination is possible, insofar as the imagination is practised. This could be done trough a constant exposure to what Tracy calls the 'classics'. In this exposure the classics should be allowed to convince us of their transendence, their power to reveal truth and their ability to transform our lives. In this respect, Tracy makes the following remark:

We must feed the imagination; we must be alert to the possible presence of some disclosure; we must recover, discover, invent, create a genre and a style, a personal voice, to render, to express the meaning of that intensified experience of something essential (Tracy 1981:129).

The creative power of the imagination is therefore not merely resident in the subjective abilities of the interpreting subject. It is actually the locus where the Wirkungsgeschichte (Gadamer) of the classics is brought to expression.

Thirdly, and on a more existential level, the analogical imagination also functions as a call for authentic conversation. It is a call for openness towards the radically different and a willingness to undergo critical self-evaluation in conversation with others:

On a more existential level, an analogical imagination suggests a willingness to enter in the conversation, that unnerving place where one is willing to risk all one's present selfunderstanding by facing the claim to attention of the other (Tracy 1987:93). 
Tracy recently actually described the analogical imagination as a belief, a conviction in the powers of conversation itself:

... the 'analogical imagination' is not only a strategy for conversation, but ... also a theological conviction ... that ultimately grounds my own trust and hope in conversation itself (Tracy 1989:514).

On the one hand, the appeal of this notion of an analogical imagination can be explained in terms of the way in which it succeeds to use differences or a radically conflicting plurality positively for the purpose of describing a theological methodology. On the other hand the importance of similarities and the own theological tradition is also emphasised and used within the explanation of the nature of theology.

In the first place, differences receives an important function. The transcendence of the object of interpretation (the classics) is the very difference of the object to the life world of the interpreting subject. What we are trying to understand when we interpret, are differences. The existence of differences thus introduces the possibility of a novum for the subject in the interpretation event. Differences and conflict could therefore actually be liberating:

If conversation is a reality, then conflict, confrontation, can prove liberating possibilities (Tracy 1981:447).

The differences in the theological conversation protect us, in the third place, from a too easy acquiescence in the established analogical relations, a harmonising attitude and the illusion that anything more than just relative adequacy is attainable.

Theological interpretation is, on the other hand, also a search for similarities. It is a search for an Einverständnis (Ebeling) or a fusion of horizons (Gadamer). It is true that a general theological consensus is, according to Tracy, neither achievable nor desireable and could be seen as wishful thinking related to a monistic approach. This does not, however, imply that a certain degree of agreement is not attainable. Indeed, this happens every time when successful communication or conversation occurs.

Another significant aspect of Tracy's proposal of an analogical imagination is the way in which he is able to respect the different particular theological traditions. The openness wanted for theological conversations does not imply a grey, monotonous synthesis between traditions. The particular tradition is of the utmost importance because it is the locus where one can start searching for a key to express the nature of the similarites between the (radically) different conversation partners. It is only through what Tracy calls a 'journey of intensification' into the particularity of our various own traditions that we can come up with suggestions for identifying similaritiesindifferences. The rediscovered truth claims of our own tradition should then be rendered available in a publicly accessable form. Only in this way can we ourselves make a worthwhile contribution to the theological conversations. ${ }^{9}$

9. See also Tracy's comments on self-respect and self-exposure (1981a:452-5). 


\section{Some theological objections to pluralism}

Several objections against a pluralistic approach to the exsiting plurality in theology can be raised.

a) The category of an openness for a legitimate, though conflicting, plurality can function as a cover up for real conflict. According to Lash (1984:90) such an openness may be

... geneigd de mate over het hoofd te zien waarin theoretische onenigheid alleen maar de abstracte uitdrukking is, in de orde van ideën, van conflicten die buiten de collegezaal of 'salon' heel vaak hardere en concretere vormen aannemen.

Pluralism could thus be a euphemism for a real bellum omnium contra omnes. It may well function, to use a South African example, as a cover up or an apology for the ideology of apartheid. This is all the more dangerous because of a possible emphasis on the idea of the 'pluriformity' (and therefore separateness!) of cultures.

b) A second relevant question to be raised is whether pluralism, with its classical liberal emphasis on openness and tolerance, is a suitable conceptual strategy to deal with what Tracy (1987:6681) calls the radical ambiguities of history. ${ }^{10}$

It is important to stress that Tracy is no supporter of a laissez-faire pluralism. His emphasis on the identification of criteria according to which all theological interpretations should be critically evaluated, is very significant in this regard. Tracy is also a strong supporter of the use of various methods of ideology critique in the interpretation event. He also emphasises the need for transformative and not only disclosive criteria of truth. The transforming power of classics for an emancipating praxis in the public realm should be explored further (Tracy 1981a:71f).

Tracy is, despite these considerations, still criticised (see Cobb 1982, Evans 1984, Welch 1988 etc.) for not being able to lay the foundations for a liberating theological praxis effectively. At the root of this critique seems to be a scepsis about Tracy's very view on the nature of theological actions as being hermeneutical. Cobb (1982: 1823) expresses, for example, the fear that the emancipating moment in theology could only exist as the practical and transformative application of disclosures. To this comment Gregory Baum (1981:290) adds:

In contrast with political theology, Tracy's systematics considers paramount the disclosure dimension of truth, to which the transformative dimension is subordinated.

It is therefore possible that, against Tracy's own intentions, these disclosures could be reduced to mere ideas which are primarily grasped cognitively and only then applied practically.

10. Gilkey (1985:728) expresses similar doubts regarding the category of play as a creative way of dealing with plurality: '... in the public realm play as the clue to existence becomes helpless and cringing whenever a new demonic absolute appears ... it is toothless if one faces oppression'. 
Recently Tracy's idea of theology as a form of conversation has also been criticised. In his hermeneutical analyses, Tracy has increasingly laid emphasis on the category of conversation as the central metaphor to describe the nature of theology (see especially 1987:126). For Tracy the hope for an emancipating theological praxis lies in conversation itself. He says:

Conflict is our actuality, conversation is our hope (1981a:363).

Conversation is the locus where conflict is resolved and where the liberating power of theological categories is generated. Tracy has a fundamental confidence in the liberating possibilities which conversation presents. For that reason the analogical imagination is no longer just a strategy for conversation, it is a deep, almost religious, conviction:

... it is a theological conviction which ultimately ground my own trust and hope in conversation itself (Tracy 1988:514).

The value of the metaphor of conversation is related to classic pluralist values like openness and inclusiveness. Sallie McFague (1989:82) says:

One of the values of Tracy's notion of theology as conversation is that it takes seriously the different contributions of many participants while decentering any one contribution as being the absolute or central one.

It is, however, still a question whether this description of theology enables one to come to terms with the radical ambiguities of history. Tracy does take the negativities very seriously, but they are negativities within what can finally be trusted. Sallie McFague (1988:500) expresses the scepsis about the adequacy of the metaphor of 'conversation' in the following way:

Should conversation be the metaphor for understanding interpretation in the closing decades of the twentieth century, a time characterized by mass poverty, genocide, ecological deterioration, political totalitarianism, nuclear escalation? Is 'conversation' adequate to address these horrors? Is it not too polite, too civilized, too Western, too elitist, too leisured, too male? ${ }^{11}$

This criticism could be regarded as unfair since, for Tracy, ideology critique and the search for a transformative and emancipating theological praxis are integrated within his understanding of conversation. But it does raise the question whether conversation as a metaphor describing the nature of theology is comprehensive enough. It might be necessary to compliment Tracy's hermeneutical description of

11. See the similar criticisms by Welch and Bernstein: 'Conversation as Tracy describes it, assumes trust. Trust between those who belong to groups that are oppressed and those who belong to groups that have been, or are still oppressive, is not gained easily, and is rarely obtained through conversation alone. The give and take of genuine conversation assumes respect by the powerful for those who are marginalized and confidence on the part of those who are marginalized. Respect and confidence are borne out of action, not of reflection. Respect and confidence are created in acts of solidarity, in acts of working together for justice' (Welch 1989:510). Bernstein (1989:87) adds: 'The danger of the appeal to interpretationasconversation is that, despite Tracy's caveats, it sounds too unproblematic and soothing as if the promise of reconciliation or the fusion of horizons can always be fulfilled'. 
theology with other possible descriptions. ${ }^{12}$ Likewise, the pluralist principles of both inclusiveness and critique, built upon a hermeneutics of both generosity and suspicion, is not necessarily adequate enough to deal with problems euphemistically called ambiguities.

d) A cultural and/or religious objection to pluralism could also be raised by pointing out the side-effects of a pluralistic culture. Langdon Gilkey describes, for example, the 'stark contradictions' or the 'painful debris of a stormy age' as follows:

On the one hand we reviewed the forces of anxiety that drive towards transcendence, towards idolatry and ideology, and towards the requirement of some absolute standpoint against both of the latter. And on the other we surveyed the even more awesome forces dissolving and repudiating any absolute center and thus seemingly any center to all. As a result, coherent reflection, meaningful commitment and creative action alike much less any reference to transcendence appear impossible (Gilkey 1985:728).

The following side-effects of a pluralistic culture could be mentioned: Berger (1979:17v) shows that the process of pluralisation necessitates the taking of decisions. Because of the subjectivity of these decisions, lacking the socially constituted objectivity of traditional worldviews, certainty and a feeling of security is hard to come by. Heisenberg's 'uncertainty principle' could be a fitting epitaph for a pluralist era. The lack of certitudes, of a fixed centre amidst a radical cultural plurality, leads to 'extreme spiritual discomfort' (Sweet 1982:723). It leads to the disintegration or privatisation of religious communities, to the loss of a sensus fidelium (Lindbeck 1989:88). Existentially this leads to a sense of anxiety reinforced by the almost apocalyptic ambiguities the late twentieth century. This 'almost visible emptying of inner life' and the 'dissolution of the soul' leads to an increasing search for an experience of transcendence (Gilkey 1985:719). This process has not only religious but also social consequences:

A quite centerless world heralds the end of creative and liberal praxis as it does of reflective theory, and thus does it represent a historical and communal disaster in which cooperative society and healthy piety are alike impossible (Gilkey 1985:727).

In such a situation a pluralist (liberal?) approach does not seem to be a viable religious option. It is manifested as an intellectualist form of spirituality, a 'religion for the Ph D crowd' (Sweet 1983:723). It is therefore understandable that some would argue for the 'cultural-anthropological necessity of a ritualistic fixing of centres' or a 'human need for absolutes' (Ellis 1981:85). A clear need for strong convictions and not only mere opinions is evident. From this perspective it is

12. See my own suggestion (1990:634) that a plurality of descriptions of the nature of theological actions might be necessary. A description of theology as a form of interpretation (or conversation) should e $g$ be critically correlated to a description of theology as an event of emancipating praxis. This correlation need not take place within the sphere of hermeneutics. 
possible to criticise the pluralistic (and liberal) tradition's exaggerated 'certainty about uncertainty:

In the punctuations of faith, the exclamation mark of an absolute, the colon of a secure conviction, the dash of a dependable axiom, the period of a 'center that holds' have been shoved aside by the supremacy of the question mark, which has come to occupy an almost iconic place in the contemporary liberal mind (Sweet 1982:722).

These remarks point in the direction of the importance (or anthropological necessity) for human beings to organise their experience and life world into allencompassing interpretation frameworks which yield meaning to one's everyday experience (cf also Gestalte). Constructs like 'ultimate concern' (Tillich), 'symbolic universes' (Berger), 'limit of experiences' (Tracy), 'God constructs' (Kaufman) ought to be understood in this light. Religion seems to function as the way in which some grip on not only a part, but the whole of reality is experienced. A pluralist acceptance of an irreducible plurality may be more problematic (than Tracy would wish to allow) within a religious context than within a philosophical context.

d) The argument in c) above deals with the powerlessness of a pluralist approach to provide us with strong convictions, with a comprehensive interpretation framework providing both security and a basis for action. The exact opposite (although related) argument can also be raised against pluralism. According to this, pluralism is in fact an allinclusive interpretation framework. It is just another form of absolute or 'ism'. It is not able to escape the monistic tendency to absolutise some or other category such as 'openness', 'inclusiveness', 'tolerance', 'interpretation' or conversation'. It is therefore a serious question whether a pluralistic approach is, finally, able to escape what Booth calls 'paradoxical umbrellas'. It might be more fruitful, and honest, to acknowledge one's own absolutes or monisms and try to explicate that as clearly as possible. In the Christian tradition this explication might take on the character of a 'witness' or a 'confession of faith'. 13

Tracy's own use of the category 'conversation' might be an example of the allinclusive character of some pluralist approaches. For Tracy, conversation is a comprehensive metaphor within which the contributions of almost every conversation partner could be included. The language of 'conviction', 'trust' and 'hope' also indicates the quasi religious role conversation plays in Tracy's thought. It forms a 'whole' within which his whole theological work is taking place.

e) A last objection to pluralism could be raised in terms of intratheological considerations. It can be asked whether a radical and irreducible plurality does have the final word in theology and whether no form of unity, no one whole or centre could be found in theology. In this context the traditional confessions of unity can be referred to. In these the Christian church have confessed over many centuries a belief in one God, one church, one faith, one Lord, one baptism. Is pluralism, therefore, a legitimate approach within, not only a philosophical or a religious, but

13. This approach might be called a pluralistically enriched return to a nontotalitarian form of monism. 
also a theological context? A thorough theological evaluation of pluralism should take these questions into serious consideration.

A comprehensive theological evaluation of pluralism is, however, rather problematic. A few comments on the question of how such an evaluation of pluralism may be done is in order.

\section{Evaluating pluralism theologically}

In evaluating pluralism theologically, it is very important to note that an attempt at ' $a$ ' theological evaluation of pluralism is problematic. The article ' $a$ ' shows maybe too little regard for the fact that different theological approaches will evaluate the desirability of pluralism in theology differently. 'A' theological evaluation can all too easily simply depart from the presuppositions of the own theological tradition. Karl Rahner (1967:104) further emphasises that:

... een volstrekt bevredigend antwoord (on the problem of pluralism in theology - EMC) zou slechts kunnen worden gegeven in een oplossing die dit pluralisme zelf nogmaals zou overkoepelen en dus in de grond van de zaak zou opheffen.

The question how such a theological evaluation of a pluralistic approach to the existing plurality in theology should be done, necessarily follows. Three different approaches could be identified in this regard:

1) Tracy's own approach to defend a pluralism in theology is regarded by some critics (Cobb 1982:284, Kaufman 1982:394, McFague 1988:500, Stout 1988:507) as inclusivist. Kaufman (1982:394) says for example:

The framework for dealing with pluralism with which Tracy seems to be operating implicitly ... is one of comprehensive inclusiveness. 14

Cobb (1982:284) adds to this:

The organization of theology which he (Tracy) proposes ... is presented too much as the organisation of theology.

Indeed, Tracy's way of doing theology is to relate various philosophical, literary, religious and theological currents and to accommodate these within the comprehensive framework provided by the metaphor 'conversation'. It is therefore a question whether a hidden form of monism or eclecticism (in which the importance of conversation is absolutised) does not appear (against Tracy's own intent) in his theology?

14. See also the somewhat sharp criticism of Stout (1989:506): 'Everyone is around the table, everyone is acknowledged, everyone is accorded respect and encouraged to speak, but the table is simply too crowded for anyone but the professor's to be heard. In the end we are apt to be impressed by the professor's remarkable erudition, his determination to discover truth in every perspective, his interest in conversation'. 
Tracy rejects the critique of inclusivism by mentioning the role of criteria and thus exclusion or even resistance in his theology (1988:514). It is clear that Tracy is not interested in accommodating all theologies in his own approach. His comment, however, tends to only emphasise the point in the sense that he works with a logic of inclusion or exclusion in trying to accommodate radically different theological currents within the framework of the metaphor of 'conversation'. Tracy's defense of plurality and pluralism in theology can perhaps be seen as a demonstration of the fruitfullness of this inclusive framework of conversation to accomodate a radical plurality of theological approaches.

2) In the light of his criticism of Tracy's theology, Gordon Kaufman (1982:393) suggests that a thorough conceptual analysis of concepts like openness, plurality and pluralism is a preferable approach to evaluate the legitimacy of plurality and pluralism in theology. Kaufman (1982:393) argues:

But it (Tracy's inclusivist approach EMC) raises questions, also, about how a theology sensitive to the acknowledged pluralism of our time should proceed. Should it attempt to digest and comprehend the great variety of religious and cultural claims made in our time, discerning and interpreting the significance of each within a great encyclopedic whole? Or should it concentrate more on the conceptual problem of defining precisely and thinking through carefully the categories which will make possible a new theological openness to and appreciation of the magnificent diversity in human life and ways of understanding, human institutions and customs, mores, and beliefs above all, in human theological claims and perspectives?

In such a conceptual analysis arguments for and against pluralism could be analysed. These can also be examined in the light of certain biblical considerations. The following arguments could be weighed up against each other: On the one hand, the irreducible wealth of meaning and nuances in the message of the gospel together with limitedness of human knowledge thereof can be mentioned (see texts like Eph 3:189, 1 Cor 13:9, 12, Rom 11:23, Eccl 3:11-12 etc.). On the other hand, the belief of the Christian church in one God, one Lord, one Spirit, one church (see texts like Deut 6:4, John 14:6, Eph 4:14) can be stressed.

One problem with this approach is that one's conceptual analysis and thus one's evaluation of pluralism will be influenced by dogmatic presuppositions, by views on the nature of Holy Scripture, by hermeneutical presuppositions and by views on the nature of theological action itself. It is therefore rather likely that, despite the attempt at a relatively objective analysis, one's evaluation of pluralism will still be biased. This approach may therefore only lead to a restructuring of the same questions within a new context.

3) A different approach would be to shift the onus of proof to the monistic opposers of pluralism. One of three possibilites then remains. a) An attempt may be made to demonstrate (with various degrees of militancy) the relative adequacy of one particular theological tradition above any other. b) One centre or fundamental core of belief can be identified which either de facto is or de iure should be common to all theological traditions. c) A comprehensive, allencompassing synthesis can be 
attempted within which all relative adequate theological traditions can feel at home. In these ways some form of unity instead of mere analogical relationships or 'family resemblances' can be established in theology.

Several keys can be used to describe the necessity and nature of the desired unity in theology. The following possibilities can be mentioned: unity through the (magisterial role of the) church as an institute, the creeds, the doctrinal decrees, the praxis and fellowship of the church, the Bible, Jesus Christ, the Holy Spirit, in eschatology etc. All of these have often been used to create some unity amidst the plurality within Christian theology.

It is neither necessary nor possible to elaborate on these attempts at finding some unity in Christian theology. A very general comment will have to suffice. It seems fair to say that none of these particular proposals have yet been able to draw a considerable degree of consensus even within the closer circles of the more conservative, orthodox or evangelical theologians. This lack of consensus implies that the unity searched for in Christian theology is still not forthcoming. The onus of proof therefore remains on the monistic opposers of a pluralistic approach. This may lead to the conclusion that the unity searched for in a monistic approach is only a regulative idea or an ultimate ideal and not a describable, demonstratable theological consensus. It is (merely) a construct used by those who would like to believe that such a unity actually exists (cf Smit 1991:1678).

Does this imply that a pluralistic approach does have the final word in Christian theology? It has to be admitted that the pluralist critique on a monistic approach in theology is, at times, devastating. There is, however, some hesitancy among many theologians to accept a consequent pluralism. This hesitancy may be the last remains of a platonian ideal or a 'cartesian anxiety' (Bernstein). But it may also be related to a desire in theology to remain theology. In the Christian tradition, it has generally been presumed that theology deals with one and the same God and not, for example, with any other gods (=idols). This theological continuity in Christian theology through all the centuries is usually emphasised when and insofar as this 'God' is understood in terms of the metaphor of personhood.

If theology deals with 'God', and if, in personal terms, it always deals with the same personal God, then 'God' does, in fact, constitute a certain unifying factor in Christian theology. 'God' is the one heading under which all theological work could be brought together. Theology may, in fact, be seen as an attempt to unify and interpret the 'whole' of our everyday experience in terms of a relationship with this 'God'. An irreducible plurality in Christian theology is, in terms of this argument, in the end suspect.

This way of arguing must surely again raise the suspicion that all Christian theology presupposes some absolute truths and cannot escape from the pitfalls characterising monistic approaches. It might, however, be argued that it is more honest, and fruitfull to acknowledge such a theological form of 'monism'. Instead of trying to evade the use of absolute, allinclusive, monistic categories (and probably get entangled in eclectic, instead of pluralist, paradoxical umbrellas), it might be more 
valuable to articulate as accurately as possible the content of such categories (which, perhaps, we all use).

Such an approach, however, still raises a few important questions. What are for example the implications of this 'theological hesitancy' for an evaluation of plurality and pluralism in Christian theology? How should a theology, conscious of the existing radical plurality in Christian theology, be done (if at all) from such a point of departure? Could such a theology be done in a way which averts the dangers and pitfalls of absolutism and monism?

These questions represent some of the most difficult problems Christian theologies have to face. Although these problems are real, some direction in the search for answers can be gathered from the Christian tradition itself. Although the Christian tradition has always held on to the belief in one and the same God, it has also traditionally spoken about this one God in different ways, i e in terms of the Father, the Son and the Holy Spirit. The formulation of a trinitarian theology and the rejection of a strict, numerical monotheism, an eclecticist sincretism, a relativist polytheism, and an agnosticist atheism can be seen as the unique way in which the Christian tradition has steered through between the extremes of monism and relativism in handling the questions regarding plurality and pluralism in theology (see Brague 1985, Moltmann 1983 and others).

A further suggestion (which I would like to investigate in future) is that a theology of love may render fruitful possibilities regarding questions on plurality and pluralism in theology. For the moment I would just like to make some introductory remarks:

\section{Pluralism, theology, love}

In the Christian tradition several concepts (e g covenant, grace, justification, Kingdom of God, hope, liberation etc) have been utilised to explain the relation between Christian convictions or between biblical data. It is, however, strange that the concept of love has received little attention from theologians in this regard although it might have the best claim to function as a key concept in theology (Gaybba 1988:33). Recent theologians like Von Balthasar (1968), Lonergan (1972), Jüngel (1978) and also McFague (1987) may count as exceptions. 15

There is no doubt that love is in fact a key concept in the Bible and the Christian tradition. Love is connected to the very person of God by the first letter of John who says that God 'is' love (1 John 4:8). Love can also function as a key to unlock a

15. It is interesting to note that Tracy also attaches great importance to love and the idea that God 'is' love. He says for example: 'The religious event described in the First Letter of John asks the question: What is the nature of ultimate reality? And the answer is: God. And, more explicitly, God is love. That is an extraordinary thought, that ultimate reality is love ... They (the classics EMC) make us aware of this great mystery that love is the basic reality. And that is what my work is all about' (quoted in Kennedy 1987:29, italics EMC). Tracy does not, however, relate the concept love to the problems of plurality and pluralism in Christian theology. 
trinitarian theology, $\mathrm{i}$ e to describe the relations between Father, Son and Spirit (Brague 1983:161).

Love can also be related to the problems of plurality and pluralism in Christian theology. This is only possible when a clear distinction is made between love as an attitude or deed and love as a relation (cf Brümmer 1984:15). Love is not only an attitude or deed of selfsacrificial charity or an ecstatic experience of mystic unification. In these cases love is a category describing a subject. However, when love is primarily understood as a relationship, it functions as an intersubjective category. Love involves a relationship existing in time and space, involving at least two parties. Loving care is not only aimed at the other party in the loving relationship, but at the healing and flourishing of the relation itself in which both parties are always already involved.

If the concept of love is developed in this direction, it could prove fruitful to the problems of plurality and pluralism in theology. This could, on the one hand, be illustrated by the inclusiveness of a loving relationship. To use a geometrical metaphor, love is not to be understood as a circle, but as an ellipse with at least two focal points (Conradie 1958:106f). The existence of a loving relation therefore presupposes and harbours plurality. Love creates room, where there is abundant space for anything that may enrich the relation.

On the other hand, love also shows an exclusive side in the sense that nothing that may be harmful to the loving relation itself is tolerated. It is therefore not true that everything is acceptable in a theology of love. It is, for example, unimaginable that a theology which considers it unnecessary to love one's neighbour, will receive general acceptance.

Furthermore, the concept of love could be valuable to describe the nature of the unity searched for in theology. It is (contra Tracy) not merely an analogical kind of relation. On the other hand, it is also not a unity which could be formulated in any final propositions. In conclusion, the diaconal and compassionate dimension of Christian love may prove helpful to prevent theologians of falling prey to the dangers of absolutism, unforbearance, arrogance and intolerance. If monisms may prove inavertable, a monism which takes love as its point of departure, may be preferable.

A Southern African postscript may be added. The concept of love lies close to the heart of Africa with its accent not on the individual, but on solidarity within the community. This is illustrated by the well-known African proverb saying: a human being is a human being through fellow human beings. The theological contribution of Africa may include a theological reflection on the nature and content of the loving relationship between God and the church of Jesus Christ established recurringly in history. This may provide a valuable correction to a theology reflecting on the nature and content of either the faith or the rebellious hope of the church. ${ }^{16}$ A theology of

16. See also Tracy's (1981a:193f, 376f) analysis of manifestation, proclamation and emancipating praxis as three relatively adequate forms of religious and Christian expression. Tracy's emphasis on the necessity of a dialectical enrichment of these forms of religious expression is echoed here. A theology reflecting on the nature and content of the faith of the church may soon become too cognitive and 
love may also, in the twentyfirst century, provide some consolation, comfort and rest for human beings in their search for cosmic security (see the term Geborgenheit). Thus we may all learn to reappreciate the answer to the first question of the Heidelberg's Catechism:

Our only comfort (Geborgenheit) in life and death is that we may belong to a loving relationship with God through the salvation in Jesus Christ (my paraphrase).

\section{WORKS CONSULTED}

Baum, G 1982. Review article: The analogical imagination: Christian theology and the culture of pluralism. Religious Studies Review 7:4, 284-9.

Berger, P 1979. The heretical imperative. Garden City: Anchor Press.

Bernstein, R J 1983. Beyond objectivism and relativism. Oxford: Basil Blackwell.

Bernstein, R J 1989. Radical plurality, fearful ambiguity and engaged hope. Joumal of Religion 69, 85-91.

Booth, W C 1979. Critical understanding: the powers and limits of pluralism. Chicago: The University of Chicago Press.

Brague, R 1983. On the Christian model of unity: the Trinity. Communio 10, 149-66.

Brümmer, V 1984. What are we doing when we pray? London: SCM Press.

Cobb, J B (Jr) 1982. Review article: The analogical imagination: Christian theology and the culture of pluralism. Religious Studies Review 7:4, 2814.

Conradie, E M 1990. Modelle van teologie as handeling. Scriptura S6, 169.

Conradie, P 1958. Die struktuur van die liefde. M A-tesis, Universiteit van Stellenbosch.

Davis, C 1974. The philosophical foundation of pluralism, in Le pluralisme: symposium interdisciplinaire, 223-250. Montreal: Dorchester.

Ellis, C 1981. Relativity, ecumenism and the liberation of the church. Baptist Quarterly 29, 81-91.

Ellul, J 1987. Theological pluralism and the unity of the Spirit, in Bradley, J E \& Müller, R A (eds), Church, world, and Spirit: Essays in honour of G W Bromiley, 215227. Grand Rapids: Eerdmans.

abstract. Likewise, a theology concentrating on the nature and content of the hope of the church (in Moltmann's sense) may become too activist and too little compassionate. A theology concentrating on the nature and content of the love of the church may perhaps equally become too esoteric, too tolerant (see also Tracy 1981a:2179). 
Evans J H 1984. Liberation, authority and the cognitive crisis in the theology of David Tracy. Union Seminary Quaterly Review 39:1, 47-62.

Fries, H 1967. Theological reflections on the problem of pluralism. Theological Studies 1967, 3-26.

Gaybba, B 1988. Love as the lamp of theology. Journal of theology for Southern Africa 65, 27-37.

Gilkey, L 1985. Events; meanings and the current tasks of theology. Journal of the American Academy of Religion 53:3, 717-134.

Jacobsen, D 1987. The rise of evangelical hermeneutical pluralism. Christian Scholar's Review 16:4, 325-35.

James, W 1909. A pluralistic universe. London.

Jennings, T W (ed) 1985. The vocation of the theologian. Philadelphia: Fortress Press.

Kaufman, G D 1975. An essay in theological method. Missoula: Scholars Press.

Kaufman, G D 1982. Conceptualizing diversity theologically. The Joumal of Religion 42, 392-401.

Kennedy, E 1986. A dissenting voice: Catholic theologian David Tracy. New York Times Magazine, 9 November 1986, 20-30.

Lash, N 1984. Theologieën in dienst van een gemeenschappelijke traditie, in Verschillende theologieën: gemeenschaplijke verantwoordelijkheid: Babel of Pinkster? Concilium 1984-1, 88-99.

Lindbeck, G A 1984. The nature of doctrine: Religion and theology in a postliberal age. Philadelphia: Westminster Press.

Lindbeck, G A 1989a. The church's mission to a postmodern culture, in Burnham, $F$ B (ed), Postmodem theology, 37-55. San Francisco: Harper \& Row.

Lindbeck, G A 1989b. Scripture, consensus, and community, in Neuhaus, RJ (ed), Biblical interpretation in a crisis. The Ratzinger conference on Bible and church, 74101. Grand Rapids: Eerdmans.

Lundin, R, Thiselton, A C \& Walhout, C 1985. The responsibility of hermeneutics. Grand Rapids: Eerdmans.

McFague, S 1987. Models of God. Theology for an ecological nuclear age. Philadelphia: Fortress.

McFague, S 1988. Review article: Plurality and ambiguity: Hermeneutics, religion, hope. Theology Today 44, 500-3.

McFague, S 1989. The theologian as advocate. Theological Education Spring 1989, 79-97.

Miles, M R 1987. Hermeneutics of generosity and suspicion: pluralism and theological education. Theological Education, Supplement 1987, 34-52. 
Moltmann, J 1985. De uitnodigende eenheid van de drieëne God in Eén God. Concilium 1985-1, 47-54.

Norris, C 1982. Deconstruction: theory and practice. London: Methuen.

Peters, T 28/9/1983. Pluralism as an theological problem. Christian Century 100, 843-5.

Peters, T 1987. David Tracy: theologian to an age of pluralism. Dialog (Minnesota) 26, 298-305.

Rahner, K 1967. Het pluralisme in de theologie en de eenheid van de belijdenis in de kerk, in Metz, J B (ed), The development of fundamental theology, Concilium 46, 95-114.

Rossouw, H W 1973. Doksologie, ortodoksie, ekumene, in Septuagesimo anno theologische opstelle aangeboden aan Prof. dr. G C Berkouwer, 203-212. Kampen: Kok.

Schillebeeckx, E (ed) 1970. Dogma and pluralism. Concilium, New York: Herder and Herder.

Stout, J 1988. Review article: Plurality and ambiguity: Hermeneutics, religion, hope. Theology Today 44, 503-9.

Sweet, L I 1983. Not all cats are gray: Beyond liberalism's uncertain faith. Christian Century 99, 721-5.

Tracy, D W 1975. Blessed rage for order, the new pluralism in theology. New York: Seabury Press.

Tracy, D W 1979. Theological pluralism and analogy. Thought: a review of culture and idea $54,24-36$.

Tracy, D W 1980. Particular questions within a general concensus. Journal of Ecumenical Studies 17, 339.

Tracy, D W 1981a. The analogical imagination, Christian theology and the culture of pluralism. London: SCM Press.

Tracy, D W 1981b. Defending the public character of theology, in Wall, J M (ed), Theologians in transition, How my mind has changed series, 113-124. New York: Crossroad.

Tracy, D W 1982. The role of theology in public life. Word \& World IV, 230-9.

Tracy, D W 1985. Theological method, in Hodgson, PC \& King, R H (eds), Christian theology: an introduction to its traditions and tasks, 35-60. Philadelphia: Fortress Press.

Tracy, D W 1987. Plurality and ambiguity: Hermeneutics, religion, hope. San Francisco: Harper \& Row.

Tracy, D W 1988. Rejoinder: Review symposium: Plurality and ambiguity: Hermeneutics, religion, hope. Theology Today 44, 513-9. 